\title{
Latin American Immigration. Public Health Implications and Challenges
}

D. J. West (Daniel J. West Jr. $)^{1,3}$, M. Mrazova (Mariana Mrazova)², E. Grey (Eva Grey)2

${ }^{1}$ Department of Health Administration and Human Resources,

University of Scranton, USA.

${ }^{2}$ St. Elisabeth University of Public Health and Social Work, SK.

${ }^{3}$ Panuska School of Professional Studies, Scranton, PA USA.

\section{E-mail address:}

daniel.west@scranton.edu

\section{Reprint address:}

Daniel J. West Jr.

Department of Health Administration and Human Resources

The University of Scranton, Scranton

PA, USA

Source: Clinical Social Work and Health Intervention

Pages: $41-44$

Volume: 11

Cited references: 6
Issue: 2

\section{Reviewers:}

Gabriela Lezcano

San Francisco, CA, USA

Mageswaari Rajoo

Bangkok, Thailand

\section{Keywords:}

Public Health. Health Care System. Immigration.

\section{Publisher:}

International Society of Applied Preventive Medicine i-gap

CSWHI 2020; 11(2): 41 - 44; DOI: 10.22359/cswhi_11_2_08 C) Clinical Social Work and Health Intervention

\section{Abstract:}

INTRODUCTION: The World Health Organization (WHO) addressed „RIGHT TO HEALTH“ in 2013 as a „fundamental right of every human being“. Globalization has changed how we interact in the global community.

METHODS: There is no single, uniform and coordinated system because of fragmented markets and differences and variations among individual states. The Affordable Care Act (ACA) debate is still a controversial topic.

RESULTS: Major global actors should link together, including public - private sector partnerships. Public health should be in the interest of the society. 
CONCLUSION: The situation of immigrants calls for a global action plan. Access to health is a global issue. Promoting access to health for all requires Global Policies. There is a need for conceptual framework while recognizing public health risks.

\section{Introduction}

The World Health Organization (WHO) addressed „RIGHT TO HEALTH“ in 2013 as a "fundamental right of every human being". Globalization has changed how we interact in the global community. (1-4)

The World Health Report 2000 suggests 3 goals for every health system:

1 Good health

2 Responsiveness to the expectations of the population

3 Fairness of financial contribution

The WHO Framework Includes 6 building blocks addressing: good service, workforce, information services, financing, leading and governance and equitable access to health care.

\section{Specific Factors Influencing the Health Care System in the United States}

There is no single, uniform and coordinated system because of fragmented markets and differences and variations among individual states. The Affordable Care Act (ACA) debate is still a controversial topic. It seems like health care is a privilege, not a basic human right.

28.5 million Americans have no health insurance. Being uninsured negatively affects health.

Social determinants of health are:

- Housing

- Employment

- Food security

- Education

- Access to care

- Transportation

These are often problematic in uninsured people which further negatively impacts their health state.

Health Care in the United States is expensive. The annual expenses are 3.5 trillion USD. Despite that, life expectancy in the USA is decreasing. Drug prices are 3-6 times higher than in Europe. Administrative costs are high. Research in health care is essential, but expensive. With more technological developments the costs of diagnosis and treatment can go up. Terrorism is yet another challenge. Still, there is a lack of commitment to universal coverage.

\section{Immigration to USA and Health Care}

There are at least three broad categories of immigrants:

- Voluntary immigrants - come to join their relatives who are already settled in the US or to fill job vacancies.

- Refugees and asylum seekers - enter the United States to avoid persecution in their country of origin.

- Undocumented immigrants - enter United States illegally.

Undocumented immigrants are not a homogenous group. There are several types including:

1 Persons that legally entered the nation state or territory, but remained there after their visa/permit expired.

2 People who applied for refugee/asylum status and were denied, but remained in the country.

3 People whose socio-economic position changed and they could not renew residence permit.

4 Individuals who used fraudulent documentation to enter.

5 Persons that entered the country unlawfully including those who were smuggled in.

Various federal, state and local policies determine health. In some cases they criminalize immigrants; in other cases they integrate immigrants through expanded rights and eligibility for health care and social services.

Deportability goals are: control of immigration enforcement, create surveillance of communicable diseases, and identify non-citizens at risk.

Expansion of eligibility and rights helps incorporating immigrants into society. It facilitates their inclusion, seeks to reduce inequalities and safeguards their human right to health.

The Federal Government has exclusive authority to regulate who enters the USA and assign their legal status. Individual states apply public 
programs and policies to non-citizens. Many immigrants live in a state of flux, surveillance, enforcement and deportation. That creates barriers to accessing health care, distrust of healthcare providers. Racialized environment can be harmful to people of color and lead to targeting people. There were numerous examples of this in Europe in the 1990s; Cuba in the 1980s; NAFTA (North American Free Trade Agreement) between Mexico, USA and Canada. These backgrounds pose a challenge for health care. We need a joint public health approach and coordinated health policies.

There are 11.5 million people in boarder communities: 42 US counties and 39 Mexican municipalities.

Boarder residents share:

- Resources and environmental problems

- Air quality

- Water quality

- Animal control

- Infectious Diseases: hepatitis A, Salmonella, tuberculosis, dengue, leprosy, rabies

- Mental health (PTSD)

- Substance abuse

In sum, immigration has significant barriers in many countries: economic, administrative, cultural, social, and political. It also poses threat of terrorism.

Barriers to health care for undocumented immigrants include:

- Lack of employment

- Financial problems

- Fear of deportation

- Discrimination

- Laws and policies

- Bureaucratic obstacles

- Public health system

Several countries, including the USA, EU states, Canada, Scandinavia, Costa Rica have policies that limit access to health care for undocumented immigrants.

\section{Conclusion}

The situation of immigrants calls for a global action plan. Access to health is a global issue. Promoting access to health for all requires Global Policies. There is a need for conceptual framework while recognizing public health risks. Safety-net healthcare facilities should concentrate on primary care, prenatal care, CDM and ef- fective vaccinations. They should include screening for prevalent infectious diseases. (5-9)

There are ethical and professional obligations involved in helping the vulnerable populations. (10) Health care providers have to have in mind cultural diversity and they need linguistic competency training. Major global actors should link together, including public - private sector partnerships. Public health should be in the interest of the society.

\section{References:}

1. KIMULI D, KOMLOSI M, SABO I, BAUER F, KARVAJ M, OTRUBOVA J, JANCOVIC $\mathrm{M}$, JANKECHOVA M, PAUEROVA $\mathrm{K}$, POLONOVA K, MATEICKA F, BARTKOVJAK M, MIKOLASOVA G, SMREKOVA E, BENCA J, DURCOVA B, DORKO D, BEDNARIKOVA M, SCHIFFERDECKEROVA M, BARKASI D, OKOTH V, MULERA M (2019) Highlands malaria among internally displaced refugees in mountain areas of $\mathrm{Ke}$ nya, Rwanda and Burundi. Lek Obz(Med Horizon)68.2019,5-6,149-150.

2. PROCHAZKOVA K, GREY E, MIKOLASOVA G, LIBOVA L, HUPKOVA I, PAUEROVA K, HOCHMAN R, JANCOVIC M, HOFBAUEROVA B, SRAMKOVA M, STA NEKOVA P, BARTKOVJAK M, MURGOVA A, KATUNSKA M, TOMANEK P, MIKLOSKOVA M, MIKLOSKO J,VLCEK R, PALENIKOVA M, DRGOVA J, KOZON V, KONOSOVA H, HRINDOVA T, OTRUBOVA J (209) Analysis of 9896 Homeless Patients. Clin Soc.Work Health Intervention $10.2019,4$.

3. KOVAC R, MIKLOSKOVA M (2013) The impact of early childhood to the risk of homelesness. Int.J.Prenat Perinat Psychol Med.,25. 2013,S1,42.

4. HAJ ALI P, PUTEKOVA S, KABATOVA J, MARTIKOVA J, ZOLLEROVA K, BUCKO L, RADKOVA, VLCEK R, GREY E, OLAH M, DURICOVA Z, SVITEK R, SIMONEK T, OTRUBOVA J, BIBZA M, KOLIBAB M, MAMOVA A, PALENIKOVA M, MURGOVA A, TKACOVA L, KALATOVA D, JANKECHOVA M, BYDZOVSKY J, KHALIL I, MICHALIKOVA L, MRAZOVA M, LISKOVA A, HERDICS G, CARNECKY M, KHALED I (2016) Are Migrants From Middle 
East Carriers of Resistant Bacteria. Clin Soc Work \& Health Intervention 7. 2016. 3,9-14.

5. HARDY M, BARTKOVJAK M, BERESOVA A, KNOSKOVA E, RADKOVA L, OTRUBOVA J, RABAROVA L, TOPOLSKAA, POLONOVA J, KALATOVA D, MIKOLASOVA G, PROCHAZKOVA K., STANKOVA P, MRAZOVA M, VALACH M, OLAH M, JACKULIKOVA M, DRGOVA J, PALENIKOVA M,
BARKASI D, OTRUBOVA J, HOFBAUEROVA B, SCHIF FER DECKEROVA M, HATAPKOVA Z, KOVAC R (2019) Is the homeles shelter population a public Health Threat? Lek Obz (Med Horizon) 68, 2019, 4, 151-152.

6. PUBLISHER LANCET. Child Nutrition. Lancet. 394. 2019, 1387. 